\title{
Comparison of The Antimicrobial Activity of Some Scutellaria orientalis L. Taxa Growing in Turkey
}

\author{
Gülderen Yılmaz ${ }^{(D)}$, Duygu Şimşek ${ }^{(\mathbb{D})}$, Nurten Altanlar ${ }^{(\mathbb{D} 2}$, Mehmet Çiçek ${ }^{(\mathbb{D})^{*}}$ \\ ${ }^{1}$ Department of Pharmaceutical Botany, Faculty of Pharmacy, Ankara University, Ankara, Turkey \\ ${ }^{2}$ Department of Pharmaceutical Microbiology, Faculty of Pharmacy, Ankara University, Ankara, Turkey \\ ${ }^{3}$ Department of Molecular Biology and Genetics, Faculty of Science and Art, Pamukkale University, Denizli, \\ Turkey
}

\begin{abstract}
Scutellaria species are commonly used in the treatment of various diseases in traditional medicine. One of the members of Lamiaceae, the genus Scutellaria L. has approximately 471 species on earth. The genus is represented by 39 taxa in Turkey which 17 of them are endemics. In this study, plant samples of $15 \mathrm{~S}$. orientalis subspecies from different regions of our country were collected and methanol extracts were prepared from aerial parts. In vitro antimicrobial activity of these extracts against three gram positive and three gram negative bacteria and against a yeast using broth microdilution method. Methanol extracts of $S$. orientalis taxa were found to have moderate to low antimicrobial activity compared to the literature.
\end{abstract}

\section{ARTICLE HISTORY}

Received: May 06, 2020

Revised: June 17, 2020

Accepted: August 10, 2020

\section{KEYWORDS}

Scutellaria orientalis,

Lamiaceae,

Antimicrobial activity

\section{INTRODUCTION}

Due to increasing resistance to antimicrobials and slowdown in the exploration of new ones, combating with infectious diseases is getting harder nowadays. Studies on extracts or compounds from plants remain important to discover new sources as antimicrobial agents. The genus Scutellaria L. (Lamiaceae) contains 471 species throughout the world [1]. Scutellaria species are generally subcosmopolitan plants and are distributed especially in the central IranTuranian region of Asia [2]. In Turkey, the genus includes about 39 taxa and 17 of these are endemics (43.6\%) [3-9].

Scutellaria orientalis L. consists 16 subspecies and 2 varieties in Turkey and most of them are endemic [3,7]. The plants have been dispersed among the East-West Anatolia and Iran-Turanian regions of Turkey. Many Scutellaria species have been used in traditional medicine for centuries. The genus has numerous biological activities such as anti-convulsant, anti-cancer, anti-diarrheal, anti-feedant, anti-hypertensive, anti-inflammatory, anti-microbial, anti-oxidant, anti-thrombotic, hepatoprotective and sedative activities [10-11]. Scutellaria species are known as "kaside, korku otu, sancı otu, şimşek otu" in Turkish. There are various uses in traditional medicine and the most common of them are as sedative in the form of

CONTACT: Mehmet Çiçek $₫$ mcicek@pau.edu.tr $\equiv$ Department of Molecular Biology and Genetics, Faculty of Science and Art, Pamukkale University, Denizli, Turkey 
hemostatic, wound healing agent and tonic in Turkey [7,12-13]. According to ethnobotanical studies in Anatolian traditional medicine, leaves of some subspecies of S. orientalis L. (subsp. orientalis, subsp. sosnowskyi (Takht.) Fed., subsp. bicolor (Hochst.) J.R.Edm., subsp. pichleri (Stapf) J.R.Edm. and subsp. virens (Boiss. \& Kotschy) J.R.Edm.) were also used as wound healer, externally, as carminative, abdominal pain relief and also used for its astringent effects [14-21].

There are many studies on the phytochemical properties of Scutellaria species. Phenolic compounds, diterpenoids were isolated by Ersöz et al. and Rodríguez et al. from S. pontica K.Koch [16, 19]. Essential oil compositions of S. albida L., S. diffusa Benth., S. heterophylla Montbret \& Aucher ex Benth, S. salviifolia Benth., S. brevibracteata Stapf, S. galericulata L. and S. tortumensis (Kit Tan \& Sorger) A.P.Khokhr. were also investigated [20-23]. Cytotoxic activity of phenylethanoid glycosides isolated from S. salviifolia was determined [24]. The acetylcholinesterase, butyrylcholinesterase and tyrosinase inhibitory activities of methanol extracts and the antioxidant activity of methanol and ethyl acetate extracts were investigated by DPPH and FRAP experiments in a study by Şenol et al. [25]. In recent years, İçen et al. investigated the chemical composition of S. orientalis subsp. virens essential oil [26]; Yavuz et al. examined antibacterial effects of S. salviifolia [27]; Zengin et al. (2018) studied antioxidant activity, enzyme inhibitory activity and phenolic components of $S$. orientalis and S. salviifolia [28]; Arttuluk et al. examined antibacterial and antifungal activity of $S$. diffusa, S. pontica K. Koch and S. salviifolia [11]; Bardakçı et al. performed flavonoid quantification of S. albida, $S$. albida L. subsp. velenovskyi (Rech.f.) Greuter \& Burdet, S. hastifolia L. and S. orientalis from Turkey [29]. In this study, we planned to investigate the antibacterial and antifungal activity of methanol extracts of 15 subspecies of $S$. orientalis using broth microdilution method.

\section{MATERIAL and METHODS}

\subsection{Plant Material}

Aerial parts of fifteen subspecies of $S$. orientalis taxa (S. orientalis L. subsp. virens (Boiss. \& Kotschy) J.R.Edm, S. orientalis L. subsp. orientalis, S. orientalis L. subsp. sosnowskyi (Takht.) Fed., S. orientalis L. subsp. bicolor (Hochst.) J.R.Edm., S. orientalis L. subsp. macrostegia (Hausskn. ex Bornm.) J.R.Edm., S. orientalis L. subsp. cretacea (Boiss. \& Hausskn.) J.R.Edm., S. orientalis L. subsp. pectinata (Benth.) J.R.Edm., S. orientalis L. subsp. pinnatifida J.R.Edm., S. orientalis L. subsp. alpina (Boiss.) O.Schwarz var. alpina, S. orientalis L. subsp. porphyrostegia J.R.Edm., S. orientalis L. subsp. carica J.R.Edm., S. orientalis L. subsp. santolinoides (Hausskn. ex Bornm.) J.R.Edm., S. orientalis L. subsp. sintenisii (Hausskn. ex Bornm.) J.R.Edm., S. orientalis L. subsp. haussknechtii (Boiss.) J.R.Edm., S. orientalis L. subsp. bornmuelleri (Hausskn. ex Bornm.) J.R.Edm.) were collected from common territories of diverse localities in Turkey. All taxa were identified according to "Flora of Turkey and the East Aegean Islands" [3] by Mehmet Çiçek. The voucher specimen are kept in the Herbarium of Ankara University Faculty of Pharmacy, Ankara, Turkey (AEF). The species names, collection localities, dates and herbarium numbers of 15 taxa are given in Table 1.

\subsection{Preparation of Extracts}

Aerial parts of $S$. orientalis taxa were dried and then powdered. About $5 \mathrm{~g}$ powdered samples were extracted with methanol $(2 \times 200 \mathrm{ml})$ in a rotary shaker for $24 \mathrm{~h}$. Extracts were filtered and further concentrated to dryness under reduced pressure at $37^{\circ} \mathrm{C}$ using a rotary evaporator (Büchi, Switzerland). Methanol extracts were obtained and kept in the freezer $+4^{\circ} \mathrm{C}$ until the experimental practices. 


\subsection{Antimicrobial Activity}

\subsubsection{Preparation of Bacterial and Fungal Suspensions}

Microorganisms used in the experiment were gram negative bacteria (Klebsiella pneumoniae ATCC 13883, Pseudomonas aeruginosa ATCC 27853, Escherichia coli ATCC 25922; gram positive bacteria Bacillus subtilis ATCC 6633, Staphylococcus aureus ATCC 29213, Enterococcus faecalis ATCC 29212 and yeast Candida albicans ATCC 10231). Microorganisms were obtained from the culture collection of the Ankara University, Faculty of Pharmacy, Pharmaceutical Microbiology Department.

Antibacterial and antifungal activity tests proceeded similarly with CLSI recommendations by broth microdilution method with some modifications [30,31]. Glycerol stocks kept at $-80^{\circ} \mathrm{C}$ were inoculated to Sabouraud Dextrose Agar (SDA, Oxoid) medium for yeast and Mueller-Hinton Agar (MHA, Merck) medium for bacteria, incubated for $20 \mathrm{~h}$ at $35 \pm 2{ }^{\circ} \mathrm{C}$. Isolated colonies from the second passage of overnight cultures transferred into $0.85 \%$ $\mathrm{NaCl}$ to obtain turbidity of $0.5 \mathrm{McF}$ arland standards. Sabouraud Dextrose Broth (SDB) medium for yeast and Mueller-Hinton Broth (MHB, Merck) medium for bacteria were used to dilute these suspensions to give a final concentration $2.5 \times 10^{3} \mathrm{CFU} / \mathrm{ml}$ for yeast and $5 \times 10^{5} \mathrm{CFU} / \mathrm{ml}$ for bacteria.

\subsubsection{Broth Microdilution Method}

Firstly, two-fold 8 serial dilutions of $S$. orientalis methanol extracts $(1000$ to $7.81 \mu \mathrm{g} / \mathrm{ml})$ were prepared in 96-well microplates using SDB media for yeast and MHB media for bacteria in $100 \mu \mathrm{l}$ volume. After serial dilution, $100 \mu \mathrm{l}$ concentration-adjusted microorganism suspensions were transferred to each well and microplates were left for incubation $(24 \mathrm{~h}$ for yeast and $20 \mathrm{~h}$ for bacteria) at $35 \pm 2^{\circ} \mathrm{C}$. Sterility and growth control wells were included. Ciprofloxacin and miconazole were used as positive controls. The well of lowest concentration with no growth was recorded as MIC $(\mu \mathrm{g} / \mathrm{ml})$ value, at the end of incubation time. All experiments conducted in two parallels.

\section{RESULTS and DISCUSSION}

\subsection{Antimicrobial Activity Results}

In this study, in vitro antibacterial and anti yeast activity of methanol extracts of fifteen S. orientalis taxa was evaluated using broth microdilution assay against the above mentioned panel of human pathogenic strains of three gram positive bacteria, three gram negative bacteria and a yeast. The results are given in Table 2 as Minimum Inhibitory Concentrations (MIC).

To the best of our knowledge and according to the literature survey, there is no report on comparative antimicrobial activity of $S$. orientalis subspecies growing naturally in Turkey. This study is the first to demonstrate that 15 subspecies of $S$. orientalis possessed in vitro antibacterial activity.

According to the results of our study, antibacterial activity values of all methanol extract of $S$. orientalis taxa were found to be between $250-62.5 \mu \mathrm{g} / \mathrm{ml}$. Antimicrobial activity scale of MIC values 500 to $100 \mu \mathrm{g} / \mathrm{ml}$ were evaluated as moderate, and MIC values less than $100 \mu \mathrm{g} / \mathrm{ml}$ were considered to be good according to the concentration ranges stated by Morales et al. (2008) [32]. As seen in Table 2, it was found that methanolic extracts obtained from the aerial parts of $S$. orientalis taxa have moderate to good antimicrobial activity. All of the species (except $S$. orientalis subsp. virens $(125 \mu \mathrm{g} / \mathrm{ml}$ MIC value) showed stronger activity $(62.5 \mu \mathrm{g} / \mathrm{ml}$ MIC value) against Gram negative $P$. aeruginosa ATCC 27853. Other gram negative bacteria, $K$. pneumoniae ATCC 13883 and E. coli ATCC 25922 were affected more than gram positive bacteria. Least affected bacteria were S. aureus ATCC 29213 and E. faecalis ATCC 29212. 
Among the extracts, $S$. orientalis subsp. orientalis, S. orientalis subsp. santolinoides and $S$. orientalis subsp. haussknechtii were the most effective ones.

Table 1. The localities of studied the subspecies of S. orientalis

\begin{tabular}{|c|c|c|c|}
\hline Scutellaria ssp. & Locality & Altitude & Collection Date \\
\hline $\begin{array}{l}\text { S. orientalis subsp. } \\
\text { alpina var. alpina }\end{array}$ & Isparta: Yalvaç, between Akşehir and Isparta & $1470 \mathrm{~m}$ & 19.05.2005 \\
\hline $\begin{array}{l}\text { S. orientalis subsp. } \\
\text { bicolor }\end{array}$ & Elazığ: Maden to Elazı̆̆ & $986 \mathrm{~m}$ & 20.05 .2006 \\
\hline $\begin{array}{l}\text { S. orientalis subsp. } \\
\text { bornmuelleri }\end{array}$ & Van: Hakkari to Van & $1383 \mathrm{~m}$ & 13.06.2006 \\
\hline $\begin{array}{l}\text { S. orientalis subsp. } \\
\text { carica }\end{array}$ & Aydın: Aydın to Karacasu & $321 \mathrm{~m}$ & 02.05 .2006 \\
\hline $\begin{array}{l}\text { S. orientalis subsp. } \\
\text { cretacea }\end{array}$ & Malatya: Kayseri between Malatya & $895 \mathrm{~m}$ & 28.05 .2005 \\
\hline $\begin{array}{l}\text { S. orientalis subsp. } \\
\text { haussknechtii }\end{array}$ & $\begin{array}{l}\text { Mardin: south of Mardin, near } \\
\text { Deyrulzafaran Monastery }\end{array}$ & $927 \mathrm{~m}$ & 30.05 .2005 \\
\hline $\begin{array}{l}\text { S. orientalis subsp. } \\
\text { macrostegia }\end{array}$ & Malatya: $34 \mathrm{~km}$ from Kemaliye to Arapgir & $1200 \mathrm{~m}$ & 22.05 .2007 \\
\hline $\begin{array}{l}\text { S. orientalis subsp. } \\
\text { orientalis }\end{array}$ & Erzincan: $45 \mathrm{~km}$ from Tercan to Erzincan & $1291 \mathrm{~m}$ & 28.06.2006 \\
\hline $\begin{array}{l}\text { S. orientalis subsp. } \\
\text { pectinata }\end{array}$ & Malatya: $2 \mathrm{~km}$ northwest of Darende & $1214 \mathrm{~m}$ & 28.05 .2005 \\
\hline $\begin{array}{l}\text { S. orientalis subsp. } \\
\text { pinnatifida }\end{array}$ & Ankara: Gölbaşı, Beynam forest & $1515 \mathrm{~m}$ & 11.06.2006 \\
\hline $\begin{array}{l}\text { S. orientalis subsp. } \\
\text { porphyrostegia }\end{array}$ & Siirt: near Botan Çayı & $530 \mathrm{~m}$ & 19.05.2006 \\
\hline $\begin{array}{l}\text { S. orientalis subsp. } \\
\text { santolinoides }\end{array}$ & Erzincan: İliç, near Boyalık village & $1160 \mathrm{~m}$ & 23.05.2007 \\
\hline $\begin{array}{l}\text { S. orientalis subsp. } \\
\text { sintenisii }\end{array}$ & Sivas: Divriği to Gedikbaşı & $1177 \mathrm{~m}$ & 25.06 .2006 \\
\hline $\begin{array}{l}\text { S. orientalis subsp. } \\
\text { sosnowskyi }\end{array}$ & Van: Güzelsu between Başkale, Güzeldere & $2757 \mathrm{~m}$ & 13.06.2006 \\
\hline $\begin{array}{l}\text { S. orientalis subsp. } \\
\text { virens }\end{array}$ & $\begin{array}{c}\text { Van: } 66 \mathrm{~km} \text { from Tatvan to Van, } \\
\text { Kuskunkıran pass }\end{array}$ & $2245 \mathrm{~m}$ & 22.06.2007 \\
\hline
\end{tabular}

Also, all of the extracts showed good activity with a value of $62.5 \mu \mathrm{g} / \mathrm{ml}$ against $C$. albicans ATCC 10231, except for S. orientalis subsp. virens, S. orientalis subsp. santolinoides and $S$. orientalis subsp. bornmuelleri since their activities were moderate with a value of 125 $\mu \mathrm{g} / \mathrm{ml}$. According to these results, all methanol extracts of $S$. orientalis taxa showed higher antimicrobial activity against yeasts than bacteria. 
Dereboylu et al. (2012) investigated antimicrobial activity of Scutellaria cypria var. cypria, S. cypria var. elatior and S. sibthorpii essential oils against B. subtilis ATCC 6633, $S$. aureus ATCC6538-P, E. faecalis ATCC 29212, Salmonella typhimurium CCM 5445, K. pneumoniae CCM 2318, E. coli ATCC 12228, P. aeruginosa ATCC 27853 and C. albicans ATCC 10239. They reported the antibacterial activity in the range of $\geq 20-10 \mathrm{mg} / \mathrm{ml}$ and antifungal activity $\geq 20 \mathrm{mg} / \mathrm{ml}$. [33].

In a study conducted in 2017, antimicrobial activity of S. salviifolia methanol extract was tested with the disc diffusion and microdilution methods. MIC results of methanol extract varied between $12,5-25 \mathrm{mg} / \mathrm{ml}$ against $E$. coli, $K$. pneumoniae, S. enteritidis $P$. aeruginosa, S. aureus [27].

Table 2. Minimum inhibitory concentration results of methanol extracts of samples (in $\mu \mathrm{g} / \mathrm{ml}$ )

\begin{tabular}{|c|c|c|c|c|c|c|c|}
\hline \multirow[b]{2}{*}{ Methanol extracts } & \multicolumn{7}{|c|}{ Microorganisms } \\
\hline & 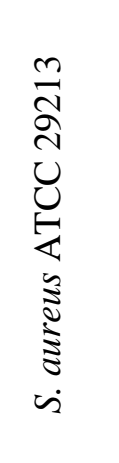 & 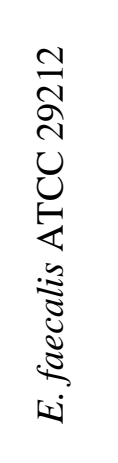 & 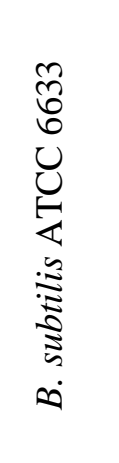 & 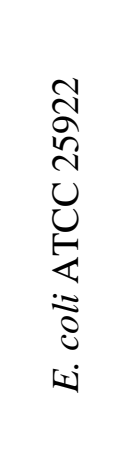 & 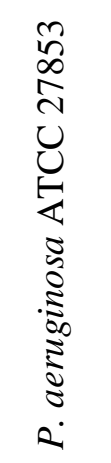 & 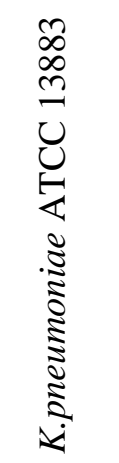 & 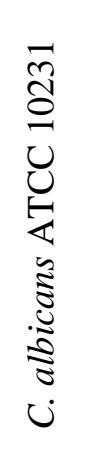 \\
\hline S. orientalis subsp. virens & 250 & 250 & 250 & 250 & 125 & 125 & 125 \\
\hline S. orientalis subsp. orientalis & 125 & 250 & 125 & 125 & 62,5 & 125 & 62,5 \\
\hline S. orientalis subsp. sosnowskyi & 250 & 250 & 250 & 250 & 62,5 & 125 & 62,5 \\
\hline S. orientalis subsp. bicolor & 250 & 250 & 250 & 125 & 62,5 & 125 & 62,5 \\
\hline S. orientalis subsp. macrostegia & 250 & 250 & 125 & 125 & 62,5 & 125 & 62,5 \\
\hline S. orientalis subsp. cretacea & 250 & 250 & 250 & 125 & 62,5 & 125 & 62,5 \\
\hline S. orientalis subsp. pectinata & 250 & 250 & 125 & 125 & 62,5 & 125 & 62,5 \\
\hline S. orientalis subsp. pinnatifida & 250 & 250 & 125 & 250 & 62,5 & 125 & 62,5 \\
\hline S. orientalis subsp. alpina var. alpina & 250 & 250 & 250 & 125 & 62,5 & 125 & 62,5 \\
\hline S. orientalis subsp. porphyrostegia & 250 & 125 & 250 & 250 & 62,5 & 125 & 62,5 \\
\hline S. orientalis subsp. carica & 250 & 250 & 125 & 125 & 62,5 & 125 & 62,5 \\
\hline S. orientalis subsp. santolinoides & 250 & 125 & 125 & 125 & 62,5 & 125 & 125 \\
\hline S. orientalis subsp. sintenisii & 250 & 125 & 125 & 250 & 62,5 & 125 & 62.5 \\
\hline S. orientalis subsp. haussknechtii & 125 & 250 & 125 & 125 & 62,5 & 125 & 62,5 \\
\hline S. orientalis subsp. bornmuelleri & 250 & 250 & 250 & 250 & 62,5 & 125 & 125 \\
\hline Ciprofloxacin & 0,312 & 0,156 & 0,078 & 0,0097 & 0,625 & 0,039 & - \\
\hline Miconazole & - & - & - & - & - & - & 1,56 \\
\hline
\end{tabular}


Arituluk et al. (2019) found that aqueous, methanol and n-butanol extracts from roots and methanol and n-butanol extracts from aerial parts of S. salviifolia, S. diffusa and S. pontica and n-hexane extracts from root parts of $S$. diffusa showed low or no antibacterial activity $(\geq 1024$ $\mu \mathrm{g} / \mathrm{ml})$. Aqueous extracts from the aerial parts showed moderate activity with the values of $1024-512 \mu \mathrm{g} / \mathrm{ml}$; chloroform, ethylacetate and $\mathrm{n}$-hexane extracts of roots and aerial parts showed low to moderate or no activity with the values of $\geq 1024-256 \mu \mathrm{g} / \mathrm{ml}, \geq 1024-256 \mu \mathrm{g} / \mathrm{ml}$, $\geq 1024-256 \mu \mathrm{g} / \mathrm{ml}$, respectively. Their anti yeast fungal activity results ranged between $\geq 1024-$ $32 \mu \mathrm{g} / \mathrm{ml}$. Chloroform extracts from roots and $n$-hexane extracts from aerial parts of $S$. salviifolia and chloroform and aqueous extracts from the aerial parts of $S$. pontica had good antifungal activity against some Candida spp. with values between $64-32 \mu \mathrm{g} / \mathrm{ml}$. And totally they found higher antifungal activity than antibacterial, in accordance with our results [11].

\section{CONCLUSION}

This study is the first report on comparative antimicrobial activity of $S$. orientalis taxa from Turkey with methanol extracts by microdilution method to the best of our knowledge. It was determined that the methanol extracts of these 15 taxa had similar levels of activity with slightly different values, which ranged between $250-62.5 \mu \mathrm{g} / \mathrm{ml}$ against all microorganisms. In the future, we plan to investigate antibacterial and anti yeast tests of different Scutellaria species and compare their results.

\section{Acknowledgements}

This research did not receive any grant or funding support from public or commercial sectors.

\section{Declaration of Conflicting Interests and Ethics}

The authors declare no conflict of interest. This research study complies with research publishing ethics. The scientific and legal responsibility for manuscripts published in IJSM belongs to the author(s).

\section{Orcid}

Gülderen Y1lmaz (iD https://orcid.org/0000-0002-6569-4766

Duygu Şimşek (D) https://orcid.org/0000-0003-1027-4139

Nurten Altanlar (D) https://orcid.org/0000-0003-2977-2269

Mehmet Çiçek (D) https://orcid.org/0000-0003-4058-3717

\section{REFERENCES}

[1]. WCSP. (2019). World Checklist of Selected Plant Families. Facilitated by the Royal Botanic Gardens, Kew. Accessed March 1, 2017 at http://apps.kew.org/wcsp/. The Plant List (2013). Version 1.1. Available online: http://www.theplantlist.org/ (accessed on 29 October 2019).

[2]. Paton, A. (1990). The phytogeography of Scutellaria L. Notes from the Royal Botanic Garden, Edinburgh, 46(3), 345-359

[3]. Edmondson, J.R. (1982). Scutellaria L. In: Flora of Turkey and the East Aegean Islands, Vol. 7, P.H. Davis Edit. Edinburgh University Press, Edinburgh. pp. 78-100. ISBN 978085-2243-96-1.

[4]. Davis, P.H., Mill, R.R., Tan, K. (1988). (Edits.), Flora of Turkey and the East Aegean Islands, Vol. 10. Edinburgh University Press, Edinburgh, pp. 202.

[5]. Duman, H., Güner, A., Özhatay, N., Ekim, T., Baser, K.H.C. (2000). Scutellaria L. In: Flora of Turkey and the East Aegean Islands, Vol. 11. Edinburgh University Press, Edinburgh. pp. 198-199. 
[6]. Çiçek, M., Ketenoğlu, O. (2011). Scutellaria anatolica (Lamiaceae), a new species from Turkey. Annales Botanici Fennici, 48(3), 276-279. https://doi.org/10.5735/085.048.0309

[7]. Çiçek, M. (2012). Scutellaria. In: Türkiye Bitkileri Listesi (Damarlı Bitkiler) Güner A, Aslan S, Ekim T, Vural M, and MT Babaç Edits. Nezahat Gökyiğit Botanik Bahçesi ve Flora Araştırmaları Derneği Yayını, İstanbul. pp. 582-585.

[8]. Çiçek, M., Yaprak, A.E. (2011). A new natural hybrid of Scutellaria (Lamiaceae) from Turkey. Phytotaxa, 29, 51-55. https://doi.org/10.11646/phytotaxa.29.1.5

[9]. Çiçek, M., Yaprak, A.E. (2013). Scutellaria yildirimlii (Lamiaceae), a new species from Turkey. Phytotaxa, 132(1), 53-58. https://doi.org/10.11646/phytotaxa.132.1

[10]. Shang, X., He, X., He, X, Li M, Zhang, R., Fan, P., Zhang, Q., Jia, Z. (2010). The genus Scutellaria an ethnopharmacological and phytochemical review. J Ethnopharmacol. 128(2), 279-313. https://doi.org/10.1016/j.jep.2010.01.006

[11]. Arituluk, Z.C., Özkul Koçak, C., Renda, G., Ekizoğlu, M., Ezer, N. (2019). Antimicrobial activity of three Scutellaria L. species from Turkey. J. Res. Pharm. 23(3), 552-558. https://doi.org/10.12991/jrp.2019.162

[12]. Baytop, T. (1999). Therapy with medicinal plants in Turkey (past and present) (2nd ed.). Nobel Tip Kitabevleri, Istanbul; ISBN 975-420-0211.

[13]. Özçelik, H., Ay, G., Öztürk, M. (1990). Some traditional plants of East and Southeast Anatolia. Proceedings of the 10th National Symposium on Biology, Atatürk University, Erzurum, pp. 1-10.

[14]. Altundag, E., Ozturk, M. (2011). Ethnomedicinal studies on the plant resources of east Anatolia, Turkey. Procedia Soc Behav. Sci., 19, 756-777. https://doi.org/10.1016/j.sbspro.2011.05.195

[15]. Çakilcioglu U, Turkoglu I. (2010). An ethnobotanical survey of medicinal plants in Sivrice (Elazı̆̆-Turkey). J. Ethnopharmacol. 132(1), 165-175. https://doi.org/10.1016/j.jep.2010.08.017

[16]. Ersöz, T., Harput, Ü.Ş., Saracoğlu, İ., Çalış, İ., Ogihara, Y. (2002). Phenolic compounds from Scutellaria pontica. Turk J. Chem., 26(4), 581-588.

[17]. Tuzlacı. E. (2016). Türkiye Bitkileri Geleneksel İlaç Rehberi, İstanbul Tıp Kitabevi, İstanbul. ISBN 978-605-4949-71-7.

[18]. Mükemre, M., Behçet, L., Çakılcıoğlu, U. (2015). Ethnobotanical study on medicinal plants in villages of Çatak (Van-Turkey). J. Ethnopharmacol., 166, 361-374. https://doi.org/10.1016/j.jep.2015.03.040

[19]. Rodríguez, B., de la Torre, M.C., Jimeno, M.L., Bruno, M., Vassallo, N., Bondì, M., Piozzi, F., Servettaz, O. (1997). Neoclerodane diterpenoids from Scutellaria pontica. J. Nat. Prod., 60(4), 348-355. https://doi.org/10.1021/np960714g

[20]. Çiçek, M., Demirci, B., Yılmaz, G., Ketenoğlu, O., Başer, K.H.C. (2010). Composition of the essential oils of subspecies of Scutellaria albida L. from Turkey. Journal of Essential Oil Research, 22(1), 55-58. https://doi.org/10.1080/10412905.2010.9700265

[21]. Çiçek, M., Demirci, B., Yılmaz G., Başer, K.H.C., (2011). Essential oil composition of three species of Scutellaria from Turkey. Natural Product Research, 25(18), 1720-1726. https://doi.org/10.1080/14786419.2010.512997

[22]. Yılmaz, G.., Çiçek, M., Demirci, B., Başer, K.H C. (2019). Essential oil compositions of subspecies of Scutellaria brevibracteata Stapf. from Turkey, Journal of Essential Oil Research (JEOR), 31(4),255-262. https://doi.org/10.1080/10412905.2019.1579762

[23]. Yılmaz, G., Çiçek, M., Demirci, B., Başer, K.H.C., (2019). Composition of the Essential Oils of Scutellaria galericulata and S. tortumensis from Turkey, Natural Volatiles \& Essential Oils (NVEO), 6(3), 1-7.

[24]. Saracoglu, I., Inoue, M., Cal1s, I., Ogihara, Y. (1995). Studies on constituents with cytotoxic and cytostatic activity of two Turkish medicinal plants Phlomis armeniaca and 
Scutellaria salviifolia. Biol Pharm Bull. 18(10), 1396-1400.

https://doi.org/10.1248/bpb.18.1396

[25]. Şenol, F.S., Orhan, İ., Yılmaz, G., Çiçek, M., Şener, B. (2010). Acetylcholinesterase, butyrylcholinesterase, and tyrosinase inhibition studies and antioxidant activities of 33 Scutellaria L. taxa from Turkey. Food and Chemical Toxicology, 48(3), 781-788. https://doi.org/10.1016/j.fct.2009.12.004

[26]. İçen, M.S., Arabac1, T., Kostekci, S., Gurhan, I. (2016). Chemical composition of the essential oil of Scutellaria orientalis L. subsp. virens (Boiss. \&Kotschy) JR Edm. from Turkey. Hacettepe Journal of Biology and Chemistry, 44(1), 25-28. doi: 10.15671/HJBC.20164417563

[27]. Yavuz, C., Dereli Kılıç, D.D., Ayar, A., Yıldırım, T. (2017). Antibacterial effects of methanol of some plant species belonging to Lamiaceae family. Int J Sec Metabolite, 4(3), 429-433. https://doi.org/10.21448/ijsm.376691

[28]. Zengin, G., Llorent-Martínez, E.J., Molina-García, L., Fernández-de Córdova, M.L., Aktumsek, A., Uysal, S., Rengasamyc, K.R.R., Aumeeruddyd, M.Z., Bahadorie, M.B., Mahomoodally, M.F. (2019). Chemical profile, antioxidant, and enzyme inhibitory properties of two Scutellaria species: S. orientalis L. and S. salviifolia Benth. Journal of Pharmacy and Pharmacology, 71(2), 270-280. https://doi.org/10.1111/jphp.13030

[29]. Bardakci, H., Turkoz Acar, E., Kirmızıbekmez, H. (2019). Simultaneous quantification of six flavonoids in four Scutellaria taxa by HPLC-DAD method. Brasilian Journal of Pharmacognosy, 29, 17-23. https://doi.org/10.1016/j.bjp.2018.09.006

[30]. Clinical and Laboratory Standards Institute. Methods for Dilution Antimicrobial Susceptibility Tests for Bacteria That Grow Aerobically. (2012). Approved StandardNinth Edition. CLSI document M07-A9 (ISBN 1-56238-783-9 [Print]; ISBN 1-56238784-7 [Electronic]). Clinical and Laboratory Standards Institute, 950 West Valley Road, Suite 2500, Wayne, Pennsylvania 19087, USA.

[31]. NCCLS. Reference Method for Broth Dilution Antifungal Susceptibility Testing of Yeasts. (2002). Approved Standard-Second Edition. NCCLS document M27-A2 [ISBN 1-56238-469-4]. NCCLS, 940 West Valley Road, Suite 1400, Wayne, Pennsylvania 19087-1898 USA.

[32]. Morales, G, Paredes, A, Sierra, P, Loyola, LA, (2008). Antimicrobial Activity of Three Baccharis Species Used in the Traditional Medicine of Northern Chile. Molecules, 13, 790-794. https://doi.org/10.3390/molecules13040790

[33]. Dereboylu, A.E., Sarikahya, N.B., Sengonca, N., Kirmizigul, S., Yasa, I., Gucel, S., Guvensen, A. (2012). Glandular Trichomes Morphology, Chemical Composition and Antimicrobial Activity of the Essential Oil of Three Endemic Scutellaria Taxa (Lamiaceae). Asian Journal of Chemistry, 24(11), 4911-4916. 